\title{
Grow with Social Enterprise: The Existence of Youth In Managing The Future
}

\author{
Chusnul Rofiah \\ *Management Department, STIE PGRI Dewantara Jombang \\ DOI: 10.29322/IJSRP.11.12.2021.p12056 \\ http://dx.doi.org/10.29322/IJSRP.11.12.2021.p12056
}

\begin{abstract}
The purpose of this article is to reveal the impact and sustainability of social enterprises even though geographically this research is located in a relatively underdeveloped and historically suburban area. This study involved seven deliberately selected target audiences of social enterprises, two coffee farmers and four informants who were interviewed with knowledge of social enterprises and their communities. This study uses a postpositivist paradigm with qualitative research methods and a phenomenological approach with a Simple Research With Triangulation Theory design (Rofi'ah and Bungin, 2021). Based on the results of the research that (1) MILLENIAL EMPOWERMENT has a strategic impact on the village so that the millennial generation continues to be active in their homes, including: Dimensions of Flexible Time, Stay In The Village, Studying Together so that there is no urbanization of the younger generation and can still keep up with the times and meet the social needs, while in determining (2) the TARGET MARKET is very profitable for the village economy because the determination of the Segmentation Dimensions, Coffee Shop Supplier, Targeting, Positioning makes RCW one of the destinations for tourists to enjoy coffee and gives a positive impression about living together in society and helps marketing coffee and cocoa farmers for tourists and the wider community. Selection of (3) MARKETING MEDIA; very supportive for tourists to know the uniqueness and atmosphere offered by RCW providing optimal comfort persuasion with the promotion on social media dimensions, Interesting Posts in the feed, Social Media Optimization, determination of (4) MARKETING STRATEGY; This social business is very interesting so that even remote locations become an option for tourists to immediately enjoy the atmosphere which is supported by tranquility and direct producer prices and below the market and supported by easy product distribution in accordance with what has been produced in this study, among others; Dimensions of Goal, Pricing Strategy (Special Price and Buy One Get One), Different Process, Distribution..
\end{abstract}

Index Terms- sustainability of social enterprises, qualitative research, millennial empowerment, impact of social enterprises

\section{INTRODUCTION}

$\mathrm{T}$ This research was conducted to answer the question how do social relationships formed in social enterprises expand and affect

people's lives? Do and how do social enterprises impact people's lives and are their impacts more widely felt? Are there welfare benefits experienced beyond the bounds of involvement in social enterprises? The community as consisting of the built environment and the people who work there. A community that is built through continuous interaction between aspects of the community related to the location (Cresswell, 2014, P. 7), and consists of networks and flows of relationships (Massey, 1997), experienced differently by different target audiences and at different times, alone or together (Doughty, 2013). In this regard, while acknowledging that the community is diverse and understood (McGregor, 2012), The concept of community is similar to the relational sense of place. (Cresswell, 2014, P. 37) describes a place as "an embodiment" of a relationship with the world. Place is used by people who do something and in this case it is never 'finished' but is constantly being done" with the term "everyday life" (Certeau, 1984, P. 16-18) to indicate that this study is talking about the mundane, not the particular, of working in a "practice, mixed ritual" and emergency" community that is "all circulating and rather tedious". Community welfare has been described as involving citizen safety, empowerment, socioeconomic security, social cohesion and social inclusion (Miles et al, 2008). Here, we do not consider what contribution social enterprises make to the predefined concept of social welfare; Beginning exploration of how social enterprises can affect the well-being of target audiences and other people in people's daily lives.

As a social enterprise, Republik Coffee Wonosalam can be considered a "social work integration" enterprise" (RCW), intended to provide social support, build social capital and provide supported jobs for millennials who are vulnerable to social needs (Barraket et al., 2010). On the surface, RCW appears to be a "Café with Millennial Workers from Karang Taruna", which is an organization located in the Wonosalam area and aims to provide traditional and modern coffee with coffee from Wonosalam coffee farmers. RCW is more than this and is open to all people in need and combines café activities such as art classes. The goal is equality and provide purpose through meaningful activities RCW raises funds from coffee sales, and the organization's business activities Social enterprises have a 
social mission, making goods for sale and providing services (Barraket et al., 2010).

Geographically, this research is located in a relatively underdeveloped and historically suburban area. One of the coffee shop places with Wonosalam's signature menu is the Wonosalam Coffee Republic (RCW) which is directly opposite PDP Argowisata Panglungan Dusun Sumberjo Panglungan Village, Wonosalam District, Jombang Regency. The suburbs are distinguished from larger cities by boundaries formed by mountains and small rivers that serve as physical and emotional barriers to connection with the rest of the city. This study involved seven deliberately selected target audiences of social enterprises, and four interviewees with knowledge of social enterprises and communities. (Richter et al., 2006), identified from the target audience of data collection. Data were collected from the target audience of social enterprises using mapping and walk-in interviews, and from the communities involved using face-to-face interviews.

Social enterprise can be defined as part of a broader social economy and solidarity movement, an alternative to mainstream capitalist enterprise, which aims to incorporate economically viable businesses for the creation of wealth, provision of services and improving the well-being of individuals and places. (Amin, 2002). Contribution of various economic enterprises to social and cultural life. To be successful in such a paradigm, a company must be commercially viable and strive to have a positive impact on society, addressing the individual and collective well-being of local communities, for example through providing work experience or training (Ferguson and Islam, 2008; Fioritti, et al., 2014).

Categories of social support (providing especially vulnerable people with social integration opportunities and social capital development); protected employment (employing vulnerable people to produce goods/services); and supported work and integrating vulnerable people into the company's market orientation. Work integration social enterprises have become the solution to the problem of job placement of vulnerable people (Borzaga, C. and Depedri, n.d., P. 97).

Benefits for individuals and society are claimed to come from social enterprise activities (Williams et al., 2008). Recently, implementing social enterprise as a form of community solution intervention, although evidence for this support remains sparse (Roy, et al, 2013). The benefits to the individual are related to achieving harmony (Antonovsky, 1979) and acquire "the skills and confidence to manage the demands of life, to respond to an environment that is both understandable and manageable" (Roy, et al, 2013, P. 61). Collective benefits identified in the literature result from operating social enterprises in rural communities (Barraket et al., 2010). The impact of social enterprises on welfare development is difficult to measure and measure. In particular, there is a poor understanding of causal mechanisms (Roy,et all, 2014).

\section{LITERATURE REVIEW}

A systematic literature review on the social impact of company-led activities on health and well-being found several quality studies (Roy, et all 2014), which showed improvements in mental health, self-confidence, self-esteem, motivation and life satisfaction. Coffee is one of the most popular drinks in the world and has grown steadily in commercial importance over the last 150 years (Daglia et al., 2000), (Sunarya et al., 2019) The cafe industry is one type of business that is rapidly spreading along with changes in people's lifestyles that are growing rapidly. according to Yuswohady, (2016)iMillennial Generation (Millennial Generation) is a generation born in the early 1980s to 2000. According toiPapilaya, n.d. that empowerment is an effort to build community capacity, by encouraging, motivating, raising awareness of their potential and trying to develop that potential into real action.

\section{RESEARCH METHODOLOGY}

This study uses a postpositivist paradigm with qualitative research methods and a phenomenological approach with a Simple Research With Triangulation Theory design. (Rofi'ah and Bungin, 2021). Phenomenology is the approach used in this study. The aim of phenomenology, once summarized, is to explain human hypotheses about the visible phenomena that arise from human consciousness and the meaning behind what appears, as well as the aspects that arise from it, the subjective aspects of people's daily lives. To know it, we must enter the world of consciousness. From the subjects studied. Phenomenological studies try to explain or interpret the meaning of a concept or phenomenon experienced based on individual awareness (Sugiono, 2018).

\section{DISCUSSION}

\subsection{MILLENIAL EMPOWERMENT}

\subsubsection{Flexible Time}

Millennials are the generation born in 1977-1998, who are now 39-18 years old. They occupy the productive age, the productive age range is 15-64 years. Most millennials aged 19-28 years have more flexible and easier time to think more creatively so they can work more productively.

"The problem is that they are more flexible, too many of our customers are millennials, and about their time, they also have a lot of flexible time" (Diana 2021). 
If positioned as a coffee barista, it is more relevant to coffee visitors who are the majority of the millennial generation, so this can be a special pleasure when coffee waiters and customers are the same as the millennial generation as stated by the informant.

\subsubsection{Stay in the Village}

Most parents want to have children who are successful and work in a clean place, like the Minside in the Wonosalam area, as stated by the informant that most Wonosalam children when they graduate want to work outside.

"On average, all RCW employees use local children, so usually in the village the mindside is school, high school continues to look for work outside, if one of the goals of RCW is so that we don't have to look for work outside, we can still be creative in the area, can't we? looking for work outside" (Diana 2021)

Answering all of that, the purpose of Republik Coffee Wonosalam RCW is to provide jobs to the Millennial generation so that they don't have to look for work outside because they can still be creative even in the area because Wonosalam has the potential for supporting nature, especially coffee trees.

"Dijak kerjo wong liyo ngunu, I'm in high school, second grade, uploading third grade, dijak kerjo, mbek, wonge, wes, uploading in 3rd grade, mas lek eman, school, Ngge, keep on listening, jenengg e areek enom wants to work, sec jobo, jare arek-arek laugh at the experience of Sekkono rono-rono, he continues to work hard for a year and a half and he can't stand metu ndek oma maringunu 2018 maringunu RCW move, rene, yo I'm still waiting to see you're here" (Andre, 2021)

The informant named Andre, he is one of the employees who have served in the Republic of Coffee Wonosalam (RCW) since early 2016, but he has worked in the dilar and left the Republic of Coffee Wonosalam (RCW) over time he was called again by the owner of the Republik Coffee Wonosalam (RCW) to come again as an employee at Republik Coffee Wonosalam (RCW) until now in 2021.

\subsubsection{Studying together}

"I think it's really important sometimes if they work here other than they work for money, they learn that later they are able to create new businesses so we also have an internship class, indeed mostly for those who take internship classes so that they can continue they want to start a new business so according to I'm really important" (Diana 2021)

Every human being will experience a learning process in his life. The learning process is carried out by attending formal, informal, and non-formal education. For humans, learning is a process to achieve various kinds of abilities, skills, and attitudes. Understanding learning in a nutshell is a relatively permanent change in behavior as a result of experience. In essence, learning is a psychological process that occurs within the individual. If the learning process goes well, the learning outcomes obtained will also be good.

Likewise with the employees of Republik Coffee Wonosalam (RCW) they not only work as coffee baristas but they are always learning there, as the informant said they learn to solve their problems besides that, employees there are not only taught to mix coffee, and serve customers but also taught how to create a new business so that when they leave they get their business supplies, and Republik Coffee Wonosalam (RCW) also accepts vocational students who want to do an internship at Republik Coffee Wonosalam (RCW) so that with this it can be said to study together other than in the coffee field. .

\subsubsection{Studying together}

"Empowering millennials is more about learning together, but the point is that we can continue to be a good thing for them to talk to because sometimes they are more open to us to talk about their lives at that time, so apart from work, they take part in controlling the role, it's juvenile delinquency too when it comes to coffee shops. That's usually where young people get together if we are comfortable to talk to they will tell us a lot of things, for example, about the topic of talking about drugs, people talk about alcohol and we can provide input for them" (Diana 2021)

In addition to learning together, millennial empowerment is very important because the millennial generation has different characteristics or characteristics of the millennial generation based on region and socio-economic conditions. However, this generation is generally characterized by increased use of and familiarity with communications, media, and digital technologies. This makes them difficult to separate from technological devices such as smartphones and laptops, which have become part of daily activities. This generation realizes that the internet has brought many conveniences to their lives. Not surprisingly, this millennial generation takes advantage of technological advances as an opportunity to do business. As a new driver of the creative economy, the use of social media platforms such as Facebook, Instagram.

With technological advances like this, it is necessary to control the Republic of Coffee Wonosalam (RCW) to the millennial generation so that they do not fall into negative things such as drugs and alcohol. Social media is currently a trend, for example, Instagram and Facebook, therefore there are positive things to do by empowering millennials for coffee businesses because they are relevant to the millennial generation with today's technology.

"It's important, right, for example, millennials like me, my friends can be invited here, the goal is the same, bro, I want to introduce Wonosalam coffee to the children here, for example, to children from Jombang and Mojokerto from out of town. Unfortunately, I know that on ig it said two people came here directly, mas, what is the name of RCW, is it getting lost everywhere?" (Toni 2021)

The millennial generation also influences to find a target market because every child who works in Republik Coffee Wonosalam (RCW) has many friends and communities so it is easier to introduce coffee and products of Republik Coffee Wonosalam (RCW) to others people outside the city such as Mojokerto.

"If the goal is to make money and add friends" (Toni 2021) 


\subsection{TARGET MARKET}

\subsubsection{Segmentation}

"If the segmentation is more of us, the first is tourists from outside the Wonosalam area at noon, then at nighttime, local people are the target market, if for age it is free, there is no certain age segmentation" (Diana,2021)

Segmentation is the art of identifying and reading emerging opportunities in the market. And at the same time segmentation is to see the market based on the variables that develop in society. In looking at the market, companies must be innovative and creative to respond to market changes, because segmentation is the beginning to determine the company's overall activities.

Wonosalam is a sub-district in Jombang Regency, East Java Province, Indonesia. This district is located at the foot and slopes of Mount Anjasmoro with an average altitude of 500-600 meters above sea level. Wonosalam District is located $35 \mathrm{~km}$ southeast of Jombang District. Wonosalam sub-district is one of the largest durian producers in East Java. In addition, the Wonosalam area also has great tourism potential, especially agro-tourism because the majority of the population's livelihood is farmers.

In addition to durian, the Wonosalam area is also a producer of cloves, coffee and bananas. With the popularity of the Wonosalam district as one of the tourist attractions in Jombang and a durian producer, many tourists visit the Wonosalam district, so they are one of the target markets of the Wonosalam Coffee Republic (RCW) in during the afternoon hours, for the evening hours the target market of the Coffee Republic Wonosalam (RCW) is local children from the Wonosalam sub-district itself, for their own age, they are free from the millennial generation to the $\mathrm{X}$ generation but most of the millennial generation are for visitors to the Coffee Wonosalam Republic $(\mathrm{RCW})$.

"Young people, it's a short time here, don't you think, take a ramen tour on Sunday, Lek, on a normal day, looking for young people around here?" (Toni 2021)

4.2.2 Coffee Shop Supplier

"Yes, we supply several stalls and coffee shops for coffee and the chocolate supplies the raw materials, mostly if the chocolate is loose, the caffe is about half, then if it's outside, the coffee is just a little bit of chocolate, if the chocolate is mostly chocolate" (Diana,2021)

The quality of coffee beans is highly dependent on the proper post-harvest handling process. One of them is from the Wonosalam area, Jombang Regency, which is located in an altitude area. Of the many types of coffee sold in the market, there are 3 types, namely Rabusta coffee, Excelsa and Arabica coffee, each type of coffee has its own characteristics and has its own market, besides Wonosalam coffee there is also a cocoa tree so that Wonosalam has the potential to supply some caffee in jombang.

One of them is Republik Coffee Wonosalam (RCW) according to what the informant said that Republik Coffee Wonosalam (RCW) is one of the suppliers of coffee and chocolate in several shops in Jombang, one of which is Langgano Coffee, Mojag Coffee which is located in the sub-district of Mojoagung and Unggah Ungguh Coffee which is located in the district of Mojoagung. located in Kaliwungu, Jombang Regency, Republik Coffee Wonosalam (RCW) can also supply in the form of coffee beans or have been made into coffee powder, depending on customer requests

"Supply, mostly Jombang and Mojoagung, the theme, Ms. Diana, is a lot, bro, keep going between shops and there are people here" (Andre 2021)

\subsection{MARKETING STRATEGY}

4.3.1 RCW's goal

"Oh no, actually, why was the republic the goal, if the republic was a unitary state, the intention was to unite the coffee, my friends here, because in Wonosalam there are some who have coffee from nine different regions here, they can find coffee from nine the village earlier", (Diana,2021)

Before making a name for a coffee brand, it should be unique and also brief. If the name for the brand has these two properties, it will provide many advantages for a business. Where the unique brand name will be easier for consumers to remember, Republik Coffee Wonosalam (RCW) consumers. Because choosing a bad name will affect the image of a business that has been run.

Not just designing a name for a brand that is unique and brief. However, the name must also be easy for others to hear. So that the name will be easy to remember and easily digested by Republik Coffee Wonosalam (RCW) customers so that they are not easily forgotten. In addition, this name must also have meaning and purpose, the purpose of the name Republik Coffee Wonosalam (RCW) is to unite the coffees of farmers in various villages, taken from the name of the Republic which has the meaning of unity, by uniting the coffee of the farmers. farmers so that they can support the economy of coffee farmers in Wonosalam.

"That, Sis, keep changing the name of RCW if the name is the one who understands, Diana, Sis, it used to be the Wonosalam Coffee Republic, then after that the name of the business was there, there was a report, like in the office, you were asked, the name of the coffee republic is the same as Jember, only the name is e. republic of coffee, dadi, right here, and then you are plagiarizing" (Toni 2021) The brand name is one thing that is important as the identity of a coffee shop as stated by informant 2 that the name Republik Coffee Wonosalam (RCW) was once the same as the coffee shop in Jember, so it was added with the word Wonosalam to make it different from other coffee shop names.

\subsubsection{Pricing Strategy}

"If the strategy in determining the price we play more on quality, so even though the price goes up and down, our prices are stable because we play on quality, there is no price war, so if the product is good, we sell it at the right price, according to the cost process for production and so on. -other important things are covered like that" (Diana,2021) 
Each coffee shop has its own way of determining the price on its menu/product, some use market prices, so the prices look the same as other coffee shops, for Republik Coffee Wonosalam (RCW) itself in determining prices does not want to use market prices as stated informants because basically the current market price is a price war going on. Republik Coffee Wonosalam (RCW) determines the price by assigning a value to a product product in which there is a process so that it can produce its own character so that it can give price to the customer according to the value given by the Republic of Coffee Wonosalam (RCW), so the price is really in accordance with the process and quality provided.

"In my opinion, follow the average, depending on the price we buy the coffee, like for example RCW, buying coffee there, if the price is around 40 thousand, the coffee is priced at 5 thousand, later if the price goes up here, it goes up, following the flow, " (Vero, 2021) As stated by the informant, determining prices with the quality and conditions that exist in local farmers, for example there is an increase, the prices offered at the Coffee Wonosalam Republic (RCW) have increased, besides that quality is also a benchmark for the Wonosalam Coffee Republic (RCW) in determining prices by following community of coffee shop owners in Jombang so that they can make the value of Republik Coffee Wonosalam (RCW) so that they can determine the appropriate price, as quoted below.

"In terms of quality, sometimes, Ms. Diana has a group like those who have cafes, so they share the term e ngge, piye ngge lek, I can imagine that sometimes they obey arek-arek ngge sometimes have their own way" (Andre, 2021)

\subsubsection{Not Using Market Prices}

"No, we don't use the market price, because the current market price is a price war. What's important is that we provide a value that matches our price" (Diana,2021)

The market price is the economic price of an item on the market. Economic theory holds that market prices converge at the point where the forces of supply and demand meet. Differences on the supply side or the demand side can cause the market price for a good or service to be re-evaluated and changed. Republik Coffee Wonosalam (RCW) itself does not depend on market prices because basically there is a price war, so Republik Coffee Wonosalam (RCW) prefers to suppress the process in determining prices so that prices really depend on the product processed by Republik Coffee Wonosalam ( $\mathrm{RCW}$ ) itself, so from this it can be concluded that prices can be stable without excessive ups and downs.

\subsubsection{Different Process}

"So if you look back, the name of the coffee is the same, for example, Robusta Wonosalam coffee, but later there will be many different processes, for example the coffee is picked red or not and the coffee is roasted using a machine or using a manual hand, whether the machine uses its own custom machine or does the USA machine have a standard? certain quality, for example, the machine has been used a lot, has it been tested or do we make it ourselves, that's usually the price of green coffee and red coffee, right?" (Diana,2021). The process of processing coffee is very important for Republik Coffee Wonosalam (RCW) starting from the selection of coffee beans, roasting with standard coffee shop tools until it is ready to be served into the hands of customers or coffee shop resellers in Jombang and outside Jombang, a good process can be used with standard tools used by other coffee shops and has been tested, the process can also be measured from the selection of coffee bean maturity can be distinguished as follows for the criteria:

a) Green and Yellowish Green, this color indicates the condition of the fruit that is still young. If picked, the seeds will be pale and wrinkled. The aroma is still very weak so it is not recommended to harvest it.

b) Reddish yellow, this color indicates that the fruit has begun to ripen.

c) The aroma is starting to get stronger and it is possible to pick it.

d) Full Red, this phase indicates that the fruit is ripe. The aroma and taste have been perfectly formed. Conditions like this are the best conditions for picking them.

e) Dark Red, dark red fruit must be picked immediately because it is too ripe. The smell has started to fade. If you wait too long, it may emit an excessive earthy aroma and become unpleasant.

"The quality of the drinks is the same as the place, if in Wonosalam, there are more and more coffee shop warkop shops in the area, and emphasize the quality of the place. I'm confused about the difference here compared to the classic count, but in the modern model, it's semi-modern" (Sandra, 2021)

The process of mixing and presenting to customers is very important, as stated by the informant that Republik Coffee Wonosalam (RCW) really provides good quality to its prospective customers so that they are satisfied and want to come again to Republik Coffee Wonosalam (RCW), besides that Republik Coffee Wonosalam (RCW) also provides proper facilities to customers by providing classic model chairs in the outdoor area and providing a modern concept in the indoor area of Republik Coffee Wonosalam (RCW).

\subsubsection{Buy 1 Get 1 Free}

"That's Ms. Diana who knows, but all cafes in Wonosalam ngunu mas do buy one get one free but show the vaccine card but if I'm not mistaken it's every Friday" (Reva 2021).

One of the words that can attract consumers is free who can refuse the opportunity to have a product without having to pay for it during the 2021 pandemic. Republik Coffee Wonosalam (RCW) takes advantage of the opportunity by giving promotions to prospective customers buy 1 get 1 free every Friday by showing a card. vaccine, this is done with enthusiasm by the owner of the Republic of Coffee Wonosalam (RCW) so that it indirectly gives consumers pride by taking 1 portion given by Republik Coffee Wonosalam (RCW) just by showing the vaccine card.

\subsection{MARKETING MEDIA}

This publication is licensed under Creative Commons Attribution CC BY.

http://dx.doi.org/10.29322/IJSRP.11.12.2021.p12056

WWW.ijsrp.org 


\subsubsection{Promotion On Social Media}

"If the Wonosalam coffee republic is more about playing promotions on social media, it's also from a network of friends like that. Maybe a lot of people saw it for the first time from social media, then from friends' recommendations, and word of mouth promotion, right? They sometimes ask questions, we also have customers from Surabaya, usually on Sundays, they check from social media first and then contact us. just came here" (Diana 2021). Social media that are often used for marketing or promotion include Instagram,. Through this media Republik Coffee Wonosalam (RCW) can carry out structured and targeted promotions to prospective customers in the city of Jombang and outside Jombang, by marketing content in the form of posts on Instagram, quality pictures or videos with good captions so that many customers are attracted to it. recommending a coffee place to his friends to visit the Republic of Coffee Wonosalam (RCW) by enjoying the cool air in Wonosalam, Jombang district. The content marketed through social media is related to products or menus that will be marketed by Republik Coffee Wonosalam (RCW) to potential customers. In addition to marketing content, this Republic of Coffee Wonosalam (RCW) marketing technique is also used to market brands. The purpose of marketing the brand here is to introduce the brand in general to the community as a whole or what is often referred to as brand awareness.

"What is often is social media, the event was only an acoustic weekend night, ppkm acoustics, if I'm not mistaken around 2018 they moved here and there were no playing after that took a long time off, if I'm not mistaken, before PPKM, then continue to acoustic again every Saturday and if social media is necessary", (Toni 2021). Social media is a very important thing that is currently being done by several coffee shops, one of which is Republik Coffee Wonosalam (RCW) especially during a pandemic and many people don't want to leave the house, besides that, as stated by informant 2 that Republik Coffee Wonosalam (RCW) often perform entertainment events such as acoustics on Sunday nights, so that from here it can attract the attention of potential customers who have the potential to come to Republik Coffee Wonosalam (RCW).

"Online, while it's online, if the people here own the stalls, the shop here is the Panglungan village, North Wonosalam, which is big, only RCW. Otherwise, it's just an ordinary coffee shop. If Ms Diana used to invite stalls, the coffee uses coffee. Wonosalam himself doesn't use ready-to-eat coffee, yes, he asked me something like that on Instagram and Facebook" (Toni 2021)

One of the marketing media carried out by Republik Coffee Wonosalam (RCW) through social media Instagram and Facebook, it is true that for now these two media are very effective in carrying out marketing strategies accompanied by current technological advances so that everyone can more easily access the internet. an opportunity for a coffee shop that will introduce its products to potential customers. In addition, the owner of Republik Coffee Wonosalam (RCW) once invited several coffee shops to support local coffee and not use coffee from large factories as stated by the informant, this is a matter of pride for coffee shops in Wonosalam by daring to introduce local coffee his.

\subsubsection{Instagram posts}

Instagram is indeed very skyrocketing, as a social media that is widely used. Including for marketing or marketing matters. This makes Instagram continue to improve, including by launching a business Instagram account feature, for business people who want to market products such as their koopi shop, they can do promotions through Instagram more effectively. "Like the Instagram post, we make continuous quality interesting posts and the captions are clear and invite customers to come here, sometimes we also use endorsement services from friends, but not too often" (Diana,2021)

Republik Coffee Wonosalam (RCW) from the beginning has often promoted through Instagram because the main benefit of using Instagram specifically for the coffee shop business is that it becomes easier, but as stated by the informant, posts must be of really high quality and carried out continuously. Not only posting, but Republik Coffee Wonosalam (RCW) also collaborates with endorsers in Jombang to advertise coffee, chocolate and menus in Republik Coffee Wonosalam (RCW).

\subsubsection{Maximizing Media}

"Okay, in my opinion, nowadays, marketing strategies are maximizing social media. That's the most important thing. If you empower millennials, it's more about learning together, but the point is, it can be a good thing for them to talk to, because sometimes they are more open to each other. us to tell stories about their lives at that time, so apart from work, taking part in the control role, juvenile delinquency is also when in a coffee shop, usually young people get together. -the crowds talk about alcohol and we can provide input for them" (Diana,2021)

In the coffee shop business world, maximizing social media in marketing a product is very important because current technological advances make marketing activities shift from offline to online and become an opportunity to market products as widely as possible, but not all products are marketed through social media because each product has a different market. For now, Republik Coffee Wonosalam (RCW) is maximizing one of the social media with Instagram so that many customers visit from outside the city and within the Jombang Regency itself, besides that there are also many coffee shops that come to Republik Coffee Wonosalam (RCW) to pick up coffee beans that will be served. want to sell again.

\section{TRIANGULASI THEORY}

\subsection{MARKETING STRATEGY}

\subsubsection{Goal}

This publication is licensed under Creative Commons Attribution CC BY.

http://dx.doi.org/10.29322/IJSRP.11.12.2021.p12056

WWW.ijsrp.org 
Based on the quote above, the informant said that the choice of business name was intended to unite the coffees in various villages in Wonosalam, then the informant said that the making of the name had experienced similarities with the coffee shop in Jember. is the informant as the owner of the business, but the informant also said that the coffees were from various villages in Wonosalam.

According to (Kotler et al., 2006) A brand is a name, term, sign, symbol, design or combination that can be used as the identity of a product or service that distinguishes one seller or group of sellers from their competitors.

Based on what was conveyed by informant that the business name is very important so that it has its own identity to distinguish it from competitors, this is in line with the theory presented by Kotler which asserts that a brand is a name, term, sign, symbol, design or combination that can used as the identity of a product or service that distinguishes one seller or group of sellers from its competitors.

\subsubsection{Pricing Strategy}

Based on the quote above, the informant said that the Republic of Coffee Wonosalam (RCW) itself in determining the price did not want to use the market price as conveyed to the informant because basically the current market price was a price war. Republik Coffee Wonosalam (RCW) determines prices by giving value to a product that has a process so that it can produce its own character so that it can provide prices to customers according to the value given by Republik Coffee Wonosalam (RCW), so the price is really appropriate. with the given process and quality.

This is in line with what was conveyed by the informant that the price is determined by a separate process provided by Republik Coffee Wonosalam (RCW). According to Kotler, (2002) an amount of money that has an exchange value for the benefit of having or using a product or service. Price is a flexible marketing mix where a price will be stable in a certain period of time but in an instant the price can increase or decrease which is contained in the income from sales.

From the results of interviews with informants who stated that prices consist of several processes, this is in line with Kotler's theory which says "Price is a flexible marketing mix where a price will be stable in a certain period of time" so that researchers can conclude that prices can be flexible. according to the given process in making a product.

\subsubsection{Promosi di Media Sosial}

Based on what was conveyed by the informant that through this media Republik Coffee Wonosalam (RCW) can carry out structured and targeted promotions to prospective customers in the city of Jombang and outside Jombang, by marketing content in the form of posts on Instagram, quality images or videos with good caption so that many customers recommend coffee places to their friends to visit Republik Coffee Wonosalam (RCW). This is in line with what was conveyed by the informant that Republik Coffee Wonosalam (RCW) has promoted through social media Instagram and Facebook to find customers outside the city or in the city, but the informant also said that there are musical activities every night of the week that are not conveyed. by the informant but based on the observations in the Republik Coffee Wonosalam (RCW) post there were uploads of the music activity.

Not only that, the strategy was carried out by Republik Coffee Wonosalam (RCW) but also working with endorsers in Jombang to advertise coffee, chocolate and menus in Republik Coffee Wonosalam (RCW) this was conveyed by the informant.

\subsubsection{Different Process}

Based on what was conveyed by the informant that the process of processing coffee is very important for the Republic of Coffee Wonosalam (RCW) starting from the selection of coffee beans, roasting with standard coffee shop tools until it is ready to be served to the hands of customers or coffee shop resellers in Jombang and outside the city of Jombang, a good process can be used with standard tools used by other coffee shops and has been tested, the process can also be measured from the selection of coffee beans maturity can be distinguished as follows for the criteria. From what was conveyed by the informant that the process is very important, the informant also said that there are more and more coffee shop warkop so that Republik Coffee Wonosalam (RCW) places more emphasis on the quality of drinks and their menus. Process The process is a form of activity carried out to market products or services to prospective customers. From the existing definition, it can be concluded that the Republic of Coffee Wonosalam (RCW) makes a product with several separate processes so that this adds its own value to the Republic of Coffee Wonosalam (RCW).

\subsubsection{Buy One Get One Free}

Based on what was conveyed by an informant from the Republic of Coffee Wonosalam (RCW) taking advantage of the opportunity by providing promotions to prospective customers buy 1 get 1 free every Friday by showing a vaccine card, this was done with enthusiasm by the owner of the Republic of Coffee Wonosalam (RCW). does not directly give consumers pride by taking 1 portion given by Republik Coffee Wonosalam (RCW) just by showing the vaccine card.

\subsubsection{Physical Evidence}

What this informant said was that one of the places in the Republic of Coffee Wonosalam (RCW) has a modern and classic concept located in a cool air so that this is a concern for potential customers. Physical evidence according to Philip Kotler is evidence that owned by a service provider aimed at consumers as a consumer added value proposal. Physical evidence is a tangible form that is offered. 
Based on the theory of physical evidence, according to Philip Kotler, that physical evidence is a tangible form that is offered to consumers, Republik Coffee Wonosalam (RCW) has fulfilled the real physical evidence.

\subsubsection{Distribution}

Based on what was conveyed by the informant that to distribute products from the Republic of Coffee Wonosalam (RCW) via courier, because expeditions are cheaper, this is in line with what was conveyed by the informant that distributing their products online.

Place/distribution (place) Definition by Kotler and Gertner, (2002) is a variety of activities carried out by the company to make its products easily obtainable and available to target consumers. Distribution has a very important role in helping companies to ensure their products. This is because the purpose of distribution is to provide goods and services that consumers need and want at the right time and place. Based on the theory of Place / distribution (place) Definition according to Kotler and Gertner, (2002) that distribution is a variety of activities carried out by companies to make their products easy to obtain and available to target consumers, this is in accordance with what was conveyed by informants who distributed their products through expeditions to coffee shops in Jombang.

\subsubsection{Millennial Empowerment}

Based on the quote above, the informant that empowering millennials is very important. In addition to learning together, millennial empowerment is very important because the millennial generation has different characteristics or characteristics of the millennial generation based on region and socio-economic conditions. However, this generation is generally characterized by increased use and familiarity, this is in line with what was conveyed by the informant that millennial empowerment is very important that the millennial generation has familiarity with others so that they can introduce products from Republik Coffee Wonosalam (RCW) to friends from out of town. and sub-districts, so that it can influence to find a target market because every child who works in the Republic of Coffee Wonosalam (RCW) has many friends and communities. According to Papilaya, n.d. Empowerment is an effort to build community capacity, by encouraging, motivating, raising awareness of their potential and trying to develop that potential into real action.

According to Zubaedi, (2016), that empowerment is an effort to build that power, by encouraging, motivating, and raising awareness of its potential and trying to develop it. Similar to what Kartasasmita Ginanjar, (1996) as an Empowerment Effort. From the several definitions of empowerment above, this is in line with the data obtained from the field which states that empowerment is a very important thing to be motivated so that the millennial generation can have the potential so that they can learn together about business development with the Republic of Coffee Wonosalam.

\subsubsection{Segmentation}

Based on what was conveyed by the informant that many tourists visit the Wonosalam sub-district, so they are one of the target markets of the Republic of Coffee Wonosalam (RCW) at noon, for the evening hours the target market of the Republic of Coffee Wonosalam (RCW) is local children from the Wonosalam sub-district itself. , for the age itself, it is free from the millennial generation to the $\mathrm{X}$ generation but most of the millennial generation for visitors to the Coffee Wonosalam Republic (RCW) this is in line with other informants who said that the segmentation of the Coffee Wonosalam Republic is young people and tourists.

According to Syakir Sula and Kertajaya, (2006) Segmentation is the art of identifying and reading emerging opportunities in the market. And at the same time segmentation is to see the market based on the variables that develop in society. In looking at the market, companies must be innovative and creative to respond to market changes, because segmentation is the beginning to determine the overall activities of the company. Based on the results of interviews with informants that the segmentation of the Republic of Coffee Wonosalam (RCW) is from all segments, both the lower middle class and the upper middle class, this is in line with the theory of Syakir Sula and Kertajaya, (2006) who stated that Segmentation is the art of identifying and reading opportunities that arise in the market, while the target market opportunities of the Coffee Wonosalam Republic (RCW) are the millennial generation who know a lot about the Wonosalam Coffee Republic (RCW) from the social media of the Coffee Wonosalam Republic (RCW).

\subsubsection{Targeting}

After segmenting, the company then selects the segment to be targeted or also called targeting and by applying this targeting means an effort to place the company's resources efficiently, therefore, this targeting is called fitting strategy or accuracy. (Nembah and Ginting, 2011). In accordance with the theory conveyed by Nembah after determining the segmentation, apart from young people and tourists who are the target market of the Republic of Coffee Wonosalam (RCW), there are coffee shops in Jombang, this is in accordance with what was conveyed by the informant.

\subsubsection{Positioning}

Based on what was conveyed by the informant that Republik Coffee Wonosalam (RCW) is a supplier of coffee shops in Jombang, the product is Robusta, Excelsa and Arabica coffee, besides Republik Coffee Wonosalam (RCW) is a supplier of chocolate in several coffee shops with product characteristics. which are marketed with the characteristics of Wonosalam.

According to Kotler and Keller, (2016), Positioning is the act of designing a company's offering and image so that it has a special place in the minds of the target market. The purpose of positioning is to place the brand in the minds of consumers in order to maximize the potential benefits for the company. From the understanding of the theory above and from the results of interviews with informants, it shows that Republik Coffee Wonosalam (RCW) positions itself as a supplier of coffee and chocolate in coffee shops in Jombang and 
illustrates to the target market that Republik Coffee Wonosalam (RCW) is one of the a coffee shop whose menu has the characteristics of Wonosalam.

The results of the new ideas obtained are presented through a new thought image Sustainability Of The Social Enterprise Cafe Industry By Empowering The Millennial Community And Coffee Farmers to help facilitate understanding of the theme of grow with social enterprise which produces four variables formed from sixteen important dimensions that need to be prepared in when running social enterprises including: (1) MILLENIAL EMPOWERMENT; Dimensions of Flexible Time, Stay In The Village, Studying Together, (2) TARGET MARKET; Dimensions of Segmentation, Coffee Shop Supplier, Targeting, Positioning, (3) MARKETING MEDIA; Dimensions of Promotion on social media, Interesting Posts in the feed, Social Media Optimization, (4) MARKETING STRATEGY; Dimensions of Goal, Pricing Strategy (Special Price and Buy One Get One), Different Process, Distribution.

\section{CONCLUSION}

Based on the results of the research that (1) MILLENIAL EMPOWERMENT has a strategic impact on the village so that the millennial generation continues to be active in their homes, including: Dimensions of Flexible Time, Stay In The Village, Studying Together so that there is no urbanization of the younger generation and can still keep up with the times and meet the social needs, while in determining (2) the TARGET MARKET is very profitable for the village economy because the determination of the Segmentation Dimensions, Coffee Shop Supplier, Targeting, Positioning makes RCW one of the destinations for tourists to enjoy coffee and gives a positive impression about living together in society and helps marketing coffee and cocoa farmers for tourists and the wider community. Selection of (3) MARKETING MEDIA; very supportive for tourists to know the uniqueness and atmosphere offered by RCW providing optimal comfort persuasion with the promotion on social media dimensions, Interesting Posts in the feed, Social Media Optimization, determination of (4) MARKETING STRATEGY; This social business is very interesting so that even remote locations become an option for tourists to immediately enjoy the atmosphere which is supported by tranquility and direct producer prices and below the market and supported by easy product distribution in accordance with what has been produced in this study, among others; Dimensions of Goal, Pricing Strategy (Special Price and Buy One Get One), Different Process, Distribution.

\section{REFERENCES}

[1] Amin, A. (2002). Ethnicity and the multicultural city: living with diversity. Environment and Planning A, 34(6), 959-980.

[2] Antonovsky, A. (1979). Health, stress, and coping. New Perspectives on Mental and Physical Well-Being, 12-37.

[3] Barraket, J., Collyer, N., O’Connor, M., \& Anderson, H. (2010). Finding Australia's social enterprise sector.

[4] Borzaga, C. and Depedri, S. (n.d.). "When social enterprises do better: efficiency and efficacy integration of work in Italian social cooperatives, chapter 6." In Denny, S. and Seddon, F. (Eds), Corporate Social: Worldwide Accountability and Evaluation, Routledge, London, 85-101.

[5] Certeau, M. de. (1984). The practice of everyday life. Berkeley. CA: University of California Press.

[6] Cresswell, T. (2014). Place: an introduction. John Wiley \& Sons.

[7] Daglia, M., Papetti, A., Gregotti, C., Bertè, F., \& Gazzani, G. (2000). In vitro antioxidant and ex vivo protective activities of green and roasted coffee. Journal of Agricultural and Food Chemistry, 48(5), 1449-1454.

[8] Doughty, K. (2013). "Going together: embodied and moving production of therapy landscapes." Health \& Places, 24, $140-146$.

[9] Ferguson, KM and Islam, N. (2008). "Conceptualizing outcomes with young adults living on the streets: grounded theory approach to evaluate social enterprise interventions." Qualitative Social Work: Research and Practice, 7(2), 217-237.

[10] Fioritti, A., D’Alema, M., Barone, R., et al. (2014). "Social enterprise, vocational rehabilitation, supported jobs: work on jobs in Italy." Journal of Nervous and Mental Disease, 202(6), 498-500.

[11] Kartasasmita Ginanjar. (1996). "Reaktualisasi Nilai-nilai Kepesantrenan.” Dies Natalis XXXI IAI Cipayung, Tasikmalaya.

[12] Kotler, P. (2002). Marketing places. Simon and Schuster.

[13] Kotler, P., \& Gertner, D. (2002). Country as brand, product, and beyond: A place marketing and brand management perspective. Journal of Brand Management, 9(4), 249-261.

[14] Kotler, P., \& Keller, K. L. (2016). A framework for marketing management. Pearson Boston, MA.

[15] Kotler, P., Keller, K. L., Koshy, A., \& Jha, M. (2006). Defining marketing for the 21 st Century. Kotler, Philip and Kevin Lane. Marketing Management 12e. New Jersey: Prentice Hall, 3-31.

[16] Massey, D. (1997). A global sense of place. I T. Barnes \& D. Gregory (red.). Reading Human Geography, 315-323.

[17] McGregor, J. (2012). "Welfare, poverty and conflict (2008)", WeD Policy Brief,. ESRC Research Group on Welfare in Developing Countries Bath.

[18] Miles, RL, Greer, L., Kraatz, D. and Kinnear, S. (2008). "Measuring community welfare: a Central Queensland case study.” Australasian Journal of Regional Studies, 14(1), 73-93.

[19] Nembah, F., \& Ginting, H. (2011). Manajemen Pemasaran. Yrama Widya, Bandung.

[20] Papilaya, E. (n.d.). E. Pemberdayaan Masyarakat Miskin. Kesejahteraan SOSIAL ISUWi, 118.

[21] Richter, A. W., West, M. A., Van Dick, R., \& Dawson, J. F. (2006). Boundary spanners' identification, intergroup contact, and effective intergroup relations. Academy of Management Journal, 49(6), 1252-1269.

[22] Rofi'ah, C., \& Bungin, B. (2021). QUALITATIVE METHODS: SIMPLE RESEARCH WITH TRIANGULATION THEORY DESIGN. Develop, 5(1).

[23] Roy, MJ, Donaldson, C., Baker, R. and Kay, A. (2013). "Social enterprise: a new pathway to health and well-being?" Journal of Public Health Policy, 34(1), $55-68$.

[24] Roy, MJ, Donaldson, C., Baker, R. and Kerr, S. (2014). "The potential of social enterprises to improve health and well-being: Model A and a systematic review." Social Sciences \& Medicine, 123, 182-193.

[25] Sugiono. (2018). Metode Penelitian Pendidikan: Pendekatan Kuantitatif, Kualitatif dan R \& D. Alfabeta.

[26] Sunarya, P. A., Bernard, D. D., \& Damanik, D. M. (2019). Viewboard Implementation Based on Javascript Charts as a Media for Submitting Sales Information on a Green E-Commerce Website Light Cafe. Aptisi Transactions On Technopreneurship (ATT), 1(1), 11-19.

[27] Syakir Sula, M., \& Kertajaya, H. (2006). Marketing Syariah. Mizan. Bandung.

[28] Williams, D. R., Costa, M. V, Odunlami, A. O., \& Mohammed, S. A. (2008). Moving upstream: how interventions that address the social determinants of 
health can improve health and reduce disparities. Journal of Public Health Management and Practice: JPHMP, 14(Suppl), S8.

[29] Yuswohady. (2016). Millennial Trends 2016. http://www.yuswohady.com/2016/01/1 7/millennial-trends-2016/

[30] Zubaedi, M. A. (2016). Pengembangan masyarakat: wacana dan praktik. Kencana.

\section{AUTHORS}

First Author - Chusnul Rofiah, lecturer, STIE PGRI Dewantara Jombang and chusnulstiepgridewantara@gmail.com

Correspondence Author - Chusnul Rofiah, lecturer, STIE PGRI Dewantara Jombang and chusnulstiepgridewantara@gmail.com 